\title{
Biogenic structures in soils under a primary Atlantic Rain Forest in SE-Brazil
}

\section{Bioestruturas no solo sob vegetação florestal de Mata Atlântica primária no Sudeste do Brasil}

\author{
Geraldo José Diogo Filhos ${ }^{* 1} \bowtie(\mathbb{D}$, José Pereira de Queiroz Neto² $₫(\mathbb{D}$ \\ 1Escola Superior de Agricultura "Luiz de Queiroz", Universidade de São Paulo, \\ Piracicaba, São Paulo, Brasil \\ 2Departamento de Geografia, Faculdade de Filosofia, Letras e Ciências Humanas, \\ Universidade de São Paulo, São Paulo, Brasil \\ E-mail: jpqneto@hotmail.com \\ *E-mail para correspondência: geobelisco@hotmail.com
}

Recebido (Received): 09/12/2019 Aceito (Accepted): 11/08/2020

Resumo: As minhocas desempenham papeis importantes na formação do solo, contudo pouca atenção é dada à bioturbação pelos pedólogos. A descrição morfológica tradicional, assim como os procedimentos de caracterização física e química do solo, não contemplam as estruturas biogênicas, que nem mesmo são consideradas pelo Sistema Brasileiro de Classificação de Solos. O objetivo deste trabalho foi caracterizar as feições biogênicas como canais, câmaras e dejeções, produzidas pela atividade de minhocas no solo da Estação Biológica de Boracéia, em São Paulo. As bioestruturas foram coletadas, medidas, fotografadas e organizadas por tipo (cilíndricos e blocos irregulares) e tamanho (muito pequeno, pequeno, médio, grande e muito grande). Foram realizadas análises físicas e químicas destes materiais e do solo: granulometria, carbono orgânico, bases trocáveis $\left(\mathrm{Ca}^{2+}, \mathrm{Mg}^{2+}, \mathrm{K}^{+}, \mathrm{P}\right)$. Alguns canais biogênicos encontravam-se preenchidos por solo revolvido (as crotovinas) e outros não. As características redoximórficas são muito comuns nas paredes dos canais, porque esses dutos biogênicos contribuem para a difusão de $\mathrm{O}_{2}$ do solo e a remoção de $\mathrm{CO}_{2}$ no perfil. As dejeções têm textura arenosa, o conteúdo de carbono orgânico nelas é três vezes superior comparado ao da matriz do solo, indicando a eficiência de certos grupos ecológicos de anelídeos na incorporação de matéria orgânica em subsuperfície. Os coprólitos também apresentaram maiores quantidades de fósforo, cálcio e magnésio do que o solo. As minhocas cumprem funções fundamentais no solo, como aeração, agregação, incorporação de matéria orgânica e aumento de sua fertilidade. Portanto, os agregados biogênicos influenciam fortemente na pedogênese, especialmente na zona tropical.

Palavras-chave: Morfologia; Bioturbação; Minhocas; Pedogênese.

Abstract: Pedologists generally pay less attention to bioturbation than other soil-forming processes since morphological descriptions and/or soil analytical methods often exclude the characterization of biogenic structures. For example, bioaggregates are not even considered in the Brazilian Soil Classification System. Here, we aimed to address this shortcoming by describing and analyzing biogenic features (e.g., channels, pedotubes, and casts) produced by earthworm activity in soils. Annelid structures in Brazilian Atlantic rain forest soils were collected, measured, and photographed. The bioaggregates were organized by type (cylindrical, irregular blocks) and class (very small, small, medium, large, and very large). Physical and chemical characterization of these structures was also performed, including analyses of soil texture, organic carbon, and exchangeable bases $\left(\mathrm{Ca}^{2+}, \mathrm{Mg}^{2+}, \mathrm{K}^{+}, \mathrm{P}\right)$. Some biogenic features were filled with revolved soil (i.e. krotovinas or paleoburrows), while others were not (intact channels). Redoximorphic features were very common on the channel walls and casts, likely because these biogenic pores contribute to soil $\mathrm{O}_{2}$ diffusion and $\mathrm{CO}_{2}$ removal. The casts were found to have a sandy texture and organic carbon contents were three times greater - as also exemplified by their darker color - than the surrounding soil matrix. These factors collectively suggest the efficiency with which certain ecological groups of annelids incorporate organic matter into forest soils. Earthworm casts also contained higher quantities of phosphorus, calcium, and magnesium (exchangeable bases) than the surrounding soil. Earthworms are a fundamental part of soil functioning, contributing to essential processes such as aeration, aggregation, organic matter incorporation, 
and fertility enhancement. Therefore, earthworms and the biogenic structures they are responsible for can be considered to strongly influence pedogenesis, especially in tropical regions.

Keywords: Morphology; Bioturbation; Earthworms; Pedogenesis.

\section{Introdução}

The pedosphere is continuously shaped by its inhabitant biota, which physically and chemically modify the soil environment. These processes result in bio-structures that differ depending on organismal eating and building habits, each of which exerts its own influence on the landscape (MIKLÓS, 2012). Some soil fauna play a particularly strong role in shaping their environment (HOLE, 1981; ODUM, 1983; HOLT and LEPAGE, 2000). Ants, earthworms, and termites perform "irreplaceable regulatory functions in aeration, aggregation, fertilization, matter transfer and soil renewal from the bedrock alteration" (MIKLÓS, 1995). Due to the role they play in pedogenic processes, these invertebrates are considered "ecosystem engineers" (LAVELLE et al., 1997). This concept refers to organisms that regulate the availability of resources to other species, as they are able to create, maintain, or modify habitats (JONES et al., 1994). The reworking and dispersing of materials in soils or sediments by any form of life is called bioturbation (JOHNSON et al., 1987). Pedologists often pay little attention to this phenomenon (MEYSMAN et al., 2006) and this is particularly true in the Brazilian context, where biogenic structures are ignored for soil description, classification, sampling, and analysis.

In the "Soil Description and Sampling Field Manual", there is only one comment on the following topic: "the activity of organisms, such as earthworms, termites, ants, armadillos etc., must be highlighted in their respective environments, noting the location of maximum activity and distribution by area." It then recommends the description of biogenic structures as proposed by Melo Júnior, 2012 (LEMOS and SANTOS, 2015, p. 67).

In the chapter "Techniques in Pedology" from the book "Practicing Geography: Field and Laboratory Techniques in Geography and Environmental Analysis", the authors also mention biological factors, categorizing the influence of plants, microorganisms, and fauna. In particular, they note that: "The role of fauna is to homogenize the soil material, the differences in weathered material coming from different rocks are erased by the fauna action" (MANFREDINI et al., 2005, p. 96). The IBGE Technical Manual of Pedology (2007, n.p.) indicates that biological activity is one of the aspects to be observed in the description of soils as follows:

It refers to the action of small organisms, such as earthworms, termites, ants, and other organisms, in the soil mass. The maximum activity, locations, and the distribution in the soil layers must be recorded. Such records must be made in the item "Observations", positioned after the root's morphology description.

Oxisol is the most common soil class in Brazilian territory, present in $39 \%$ of the country area. One of its important morphological characteristics is the diagnostic horizon with micro-aggregated structure. Interestingly, the genesis of this morphology is attributed to the activity of termites, where soil and saliva is mixed in their mouths to cultivate microaggregates for the construction of their nests (MIKLÓS, 1992). These animals, which have been active since the Cretaceous period, have therefore likely played a fundamental role in the formation of these ancient, deep, and homogeneous soils that span the tropics (SCHAEFFER, 2001). Despite the critical importance of bioturbators in sculpting these soils, the words "termites", "ants", "earthworms", "fauna", or "bioturbation" are not even mentioned by Brazilian Soil Classification System, and there are only vague and sparse references to biological activity. The text recognizes that the presence of life is one of the factors that differentiates soil from other terrestrial substrates and states that "all morphological characteristics are relevant for soil characterization and classification," and weakly affirms that biogenic structures are not "particularly indispensable" (SIBCS, 2018, p. 147).

In the Guidelines for Soil Description (FAO, 2006), biogenic structures are considered only in general terms. For example, it is recommended to only register the abundance and kind (e.g.: artefacts, burrows, opened large burrows, infilled large burrows, charcoal, earthworm channels, pedotubes, termite or ant channels and nests, and other insect activity) of biogenic structure present, without any mention of sizes (with the exception of roots). Their text does recognize the biotic influence on the formation of granular and blocky subangular structures, as well as its effects on porosity. However, it does not define bio-structures, their formation processes, and their possible effects on the soil in detail, as they do for abiotic features (e.g.: 
structure, consistency, mottles). The percentage by volume of biogenic features ( $\geq 50 \%)$ was used as a third criterion for defining the voronic horizon (after the granular or fine subangular blocky structures - first, and specific values and chromas - second) and vermic qualifier in the World Reference Base for Soil Resources (IUSS Working Group, WRB, 2006). In the last edition of WRB, the voronic horizon was replaced by the chernic horizon, and the criterion requiring a specific volume of biogenic features was removed except when invoking the vermic qualifier (WRB, 2015). High animal activity is also a secondary criterion to define both anthropogenic hortic and irragric horizons $(\geq 25 \%$ ), where biological effects are coupled to agricultural influences. Organismal effects are also mentioned in the general descriptions of the Terric, Plaggic, Petrogypsic, and Argic horizons. Termites are presented as an additional feature to identify lithological discontinuity. Apart from the previously described references, WRB does not explicitly describe earthworm and ant activities, or other bioturbation processes in a more general sense (IUSS Working Group, WRB, 2015).

Considering the extensive presence but general lack of previous work on biogenic features in soils, this work aims to describe and analyze the bio-structures produced by earthworms in the soils of Estação Biológica de Boracéia (EBB), an environmental conservation area within the primary Atlantic Rain Forest of Brazil. Biogenic structures such as channels, chambers, and casts of annelids were collected, measured, and photographed, and subsequently organized by type (cylindrical and irregular blocks) and class (very small, small, medium, large, and very large). We also performed physical and chemical analyses on the casts, where within we aimed to compare and establish relationships between the biogenic soil products and surrounding bulk soil matrix.

\section{Materials and methods}

The Estação Biológica de Boracéia (EEB) study area is located between the geographical coordinates $23^{\circ} 39^{\prime} 9.85^{\prime \prime S}$ and $45^{\circ} 53^{\prime} 19.80^{\prime \prime}$ (Figure 1). It belongs to the Zoological Museum of the University of São Paulo and has maintained 96 hectares of protected forest since 1954 (TRAVASSOS FILHO and CAMARGO, 1958). The area is in the vicinity of the Serra do Mar State Park, another protected area of $3.320 \mathrm{~km}^{2}$. Because of human disturbances, the Atlantic Rain Forest is highly fragmented and considered one of the world's highest conservation priorities (MYERS et al., 2000). In the past, the area covered 1.290.000 $\mathrm{km}^{2}$. It is estimated that today only $12 \%$ of its original coverage remains, including both well-preserved sites and those with secondary vegetation (RIBEIRO et al., 2009). Research on this natural ecosystem can contribute to its conservation, and this work is warranted considering its richness in biodiversity and apparent fragility.

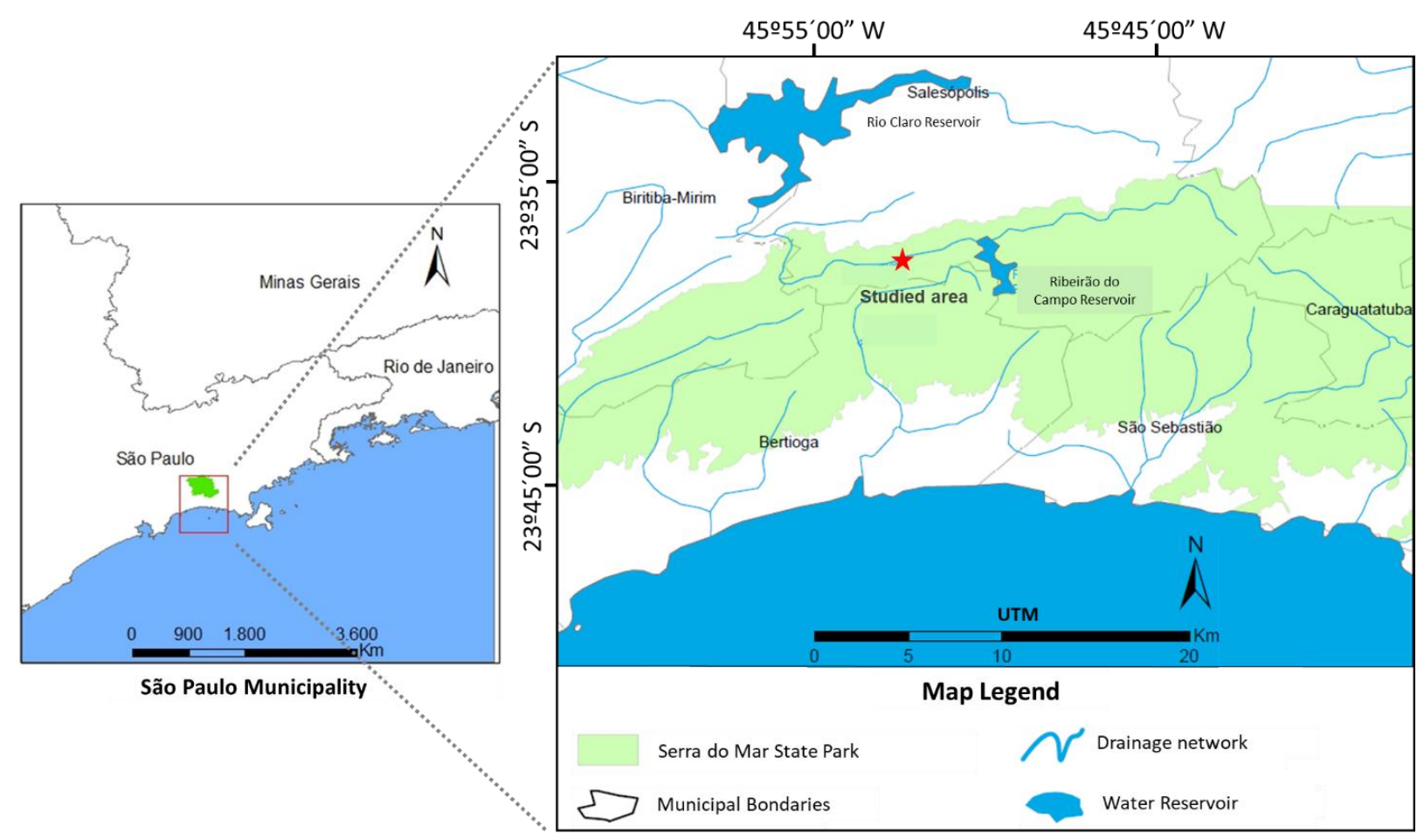

Figure 1: Studied area location. Sources: IBGE, MMA, SABESP. Elaborated by authors, 2020. 
The region is located within the geomorphological unit of the Atlantic Plateau (ROSS and MOROZ, 1997) on the Atlantic Shield Precambrian Crystalline Basement, wherein rocks from the Açungui Group (gneiss, schists, and granites) predominate. The underlying substrate at our particular sampling site is gneiss (ALMEIDA, 1974; CAMPANHA et al., 1994). The recurring soil classes are Acrisols, Cambisols, Regosols, and Leptsols (OLIVEIRA et al., 1999; ROSSI and QUEIROZ NETO, 2001; IBGE, 2005). Vegetation at the site is characterized by Ombrophilous Dense Forest (IBGE, 2012), and the climate is humid tropical (Cfa) with a mean annual temperature of $17.9^{\circ} \mathrm{C}$ and mean annual precipitation of $2018 \mathrm{~mm}$ (CUSTÓDIO FILHO, 1989).

\subsection{Biogenic structures}

Bio-structures were organized by type (i.e. granular, cylindrical, irregular blocks, and globular) and class (very small, small, medium, large, and very large). These classifications are in accordance with the detailed morphological description of biogenic structures proposed by Melo Júnior (2012), as outlined here in Table 1. Each morphological type is associated with a particular organism: (i) globular, which comes from the activity of vespids; (ii) irregular blocks, which reside in the walls of abandoned termite mounds or superficial earthworm casts; (iii) cylindrical, which are formed by filling channels created by the activity of macrofauna or roots, as well as internal annelids casts; and (iv) granular, which are formed in the oral termite apparatus and/or represent the excrement of other pedofauna such as earthworms. Each morphological type has specific size limits.

Table 1: Types and size classes of biogenic structures. Adapted from Melo Júnior (2012).

\begin{tabular}{ccccc}
\hline & \multicolumn{3}{c}{ Type } \\
\cline { 2 - 4 } Class & Granular & Cylindrical & Irregular blocks & Globular \\
\hline Very small & $<1 \mathrm{~mm}$ & $4 \mathrm{~mm}$ & $<10 \mathrm{~mm}$ & - \\
Small & 1 to $<2 \mathrm{~mm}$ & 4 to $<8 \mathrm{~mm}$ & 10 to $<20 \mathrm{~mm}$ & 10 to $<25 \mathrm{~mm}$ \\
Medium & 2 to $<5 \mathrm{~mm}$ & 8 to $<12 \mathrm{~mm}$ & 20 to $<30 \mathrm{~mm}$ & 25 to $<35 \mathrm{~mm}$ \\
Large & 5 to $<10 \mathrm{~mm}$ & 12 to $<16 \mathrm{~mm}$ & 30 to $<40 \mathrm{~mm}$ & - \\
Very large & $>10 \mathrm{~mm}$ & $>16 \mathrm{~mm}$ & $>40 \mathrm{~mm}$ & - \\
\hline
\end{tabular}

Samples were collected from three open trenches positioned at the crest, middle, and lower slope of a soil catena, where Umbrisolic, Acrisolic, and Podzolic soils have developed, respectively (IUSS Working Group WRB, 2015). Biogenic structures were present in all three soil profiles. However, the highest occurrence was observed in the middle slope, where bio-structures occurred down to $30 \mathrm{~cm}$ depth and a significant number of other bio-features arising from intensive earthworm activities were also identified.

\subsection{Physical and chemical attributes}

Casts and samples of bulk soil were collected and dried at $40^{\circ} \mathrm{C}$ for 72 hours. Fine earth fractions $(<2$ $\mathrm{mm}$ ) were used in the granulometric and chemical analyses. Following organic matter removal with $\mathrm{H}_{2} \mathrm{O}_{2}$, the sand fraction was separated using a $0.053 \mathrm{~mm}$ sieve. After sieving, sodium hexametaphosphate was used to disperse the suspension, and the clay and silt fractions were subsequently separated by sedimentation (GEE and OR, 2002). The elements $\mathrm{P}$ and $\mathrm{K}^{+}$were extracted with Mehlish-1 solution and their abundances were determined using spectrophotometry and flame spectroscopy (Digimed Dm-62), respectively; $\mathrm{Ca}^{2+}$ and $\mathrm{Mg}^{2+}$ were extracted with Ammonium Acetate $\left(1.0 \mathrm{~mol} \mathrm{~L}^{-1}\right)$ solution and determined by atomic absorption spectroscopy (Perkin Elmer 1100B). Organic carbon was extracted with a $\mathrm{K}_{2} \mathrm{Cr}_{2} \mathrm{O}_{7}, 0.4 \mathrm{~N}$ solution and titrated with a ferrous ammonium sulfate solution of $0.1 \mathrm{~N}$ (DONAGEMMA et al, 2011). An elemental analyzer (SSM-5000A) was used to perform carbon measurements.

Horizons from the three profiles opened up along the slope were collected for soil analysis. The aim was to establish a correlation between soil and the physical and chemical attributes of the bio-structures. The middle slope profile, where the greatest number of slope coprolites were conserved, was selected to represent average results. We exclusively analyzed the excrement from large worms, owing to the greater volume of material that we could collect from them (about $300 \mathrm{~g}$ ). The collected casts were homogenized in a composite sample for all further analyses. 


\section{Results and discussion}

\subsection{Biogenic structures}

We found two types of biogenic structures arising from earthworm activity in these forest soils: casts and pedotubes (channels). Melo Júnior (2012) suggested that worm casts present two dominant forms: (i) cylindrical shape, usually representing internal excretions, wherein the outer ringed surface is comprised by the successive fitting of concave shapes in the direction of the digestive tract; and (ii) irregular blocks, usually assumed to represent external excretions. In this work, some internal excretions in the shape of irregular blocks were observed, as were external dejections with cylindrical shapes. Figure 2 presents a summary of some dimensions of coprolites and pedotubules found in the field. The size of these structures, as well as their frequency of occurrence, implicates the importance of bioturbation processes. It shows the massive turnover capacity of earthworms in this environment, and highlights the impact of this process at different levels of soil organization, from individual aggregates to soil pedons, and even up to the landscapescale.

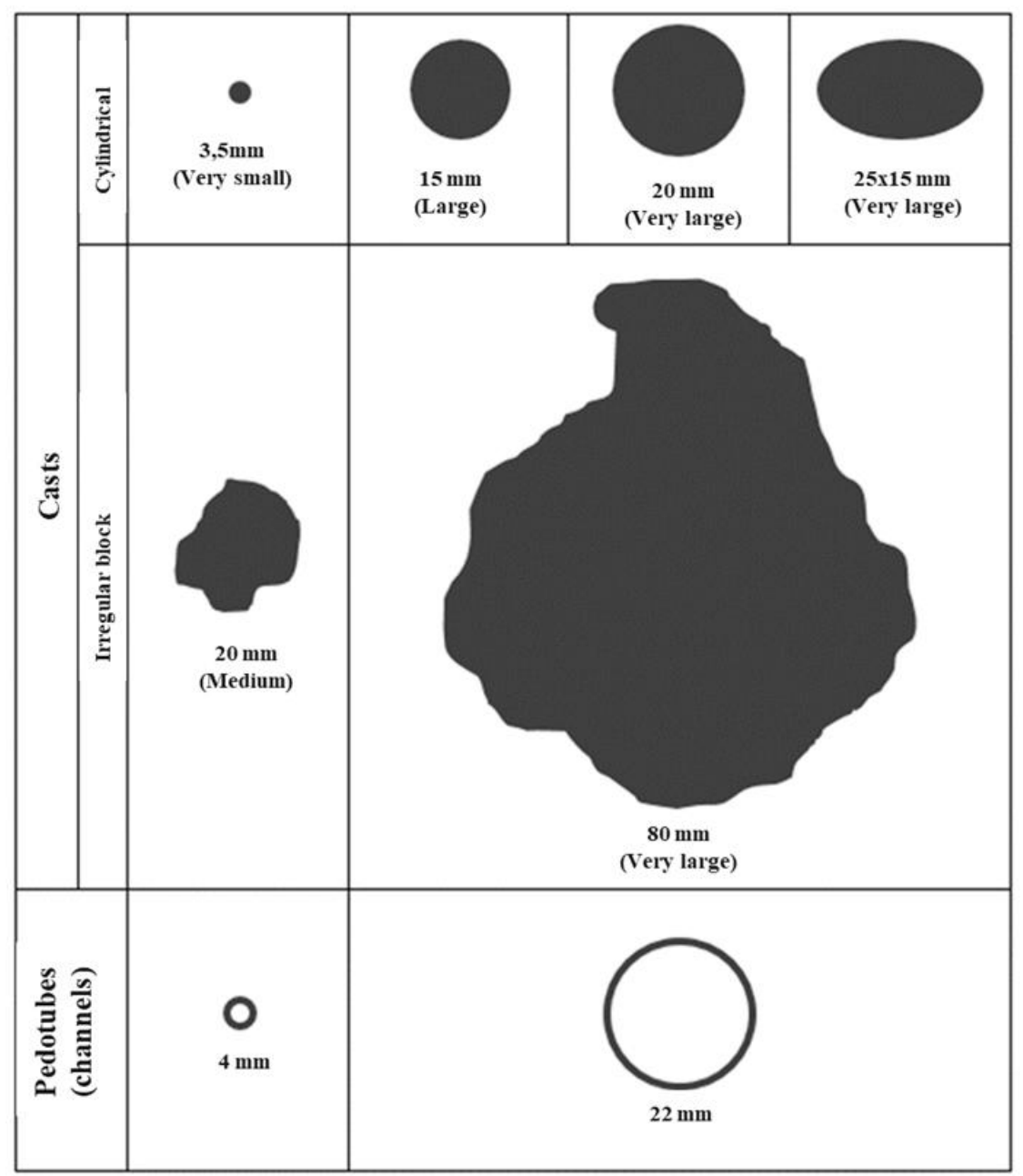

Figure 2: Examples of casts and channels sizes found. Source: Elaborated by authors, 2020.

\subsubsection{The casts}

The casts samples were grouped into two prevailing types: cylindrical and irregular blocks. The irregular blocks, despite having already lost many of their morphological characteristics, still retained some shapes that invoke their biological origins, such as cylindrical components and some characteristic rings (Figures 3A and 3B). Their presence varied between the medium (from 20 to $<30 \mathrm{~mm}$ ) and very large (> $40 \mathrm{~mm}$ ) classes, and they differed equally in relation to the bulk soil color. The cylindrical casts varied in both color and size, and typically landed between the small (between 4 and $<8 \mathrm{~mm}$ ) and very large $(>16 \mathrm{~mm}$ ) classes. 


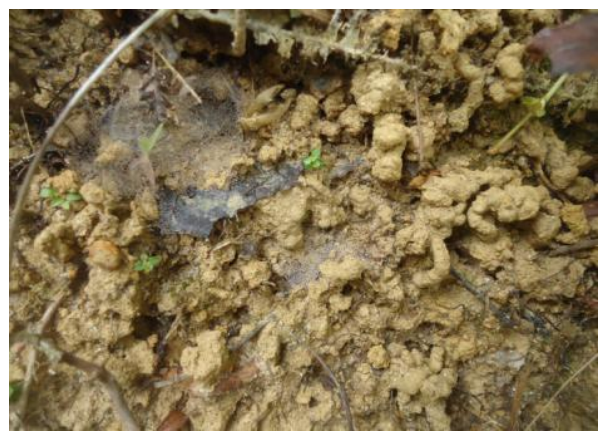

A - External casts in cylindrical and irregular blocks shapes of small size

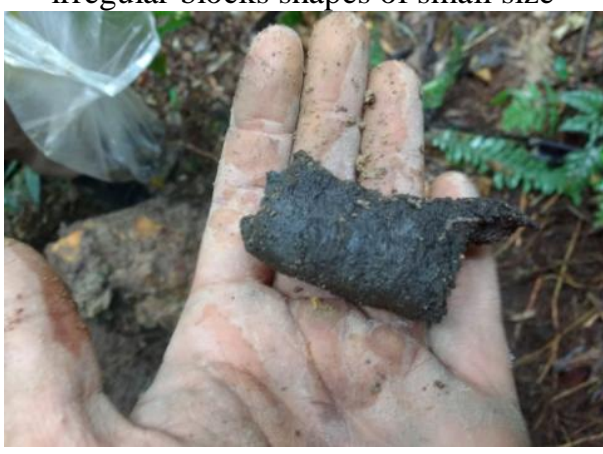

C -Cylindrical cast that is very large with dark color

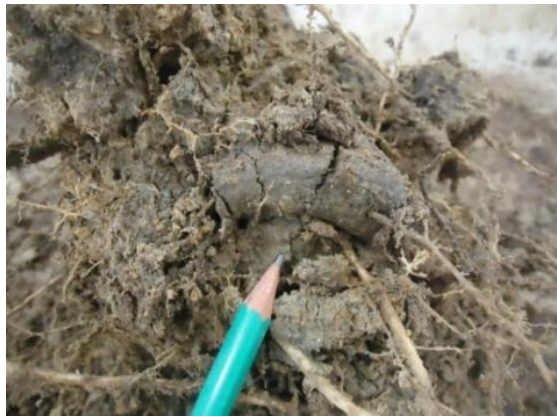

E - Cylindrical casts in same color than bulk soil

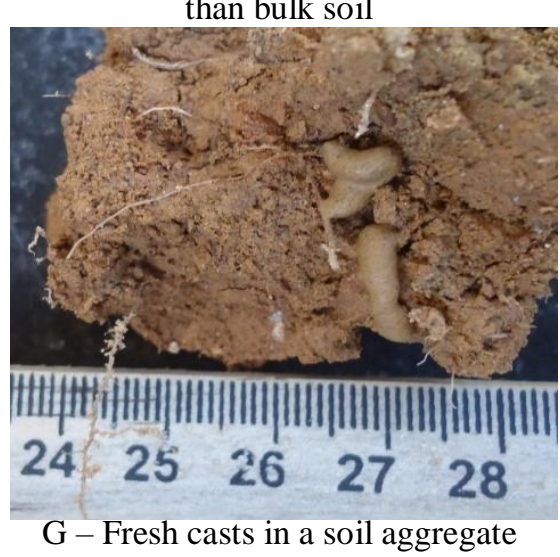

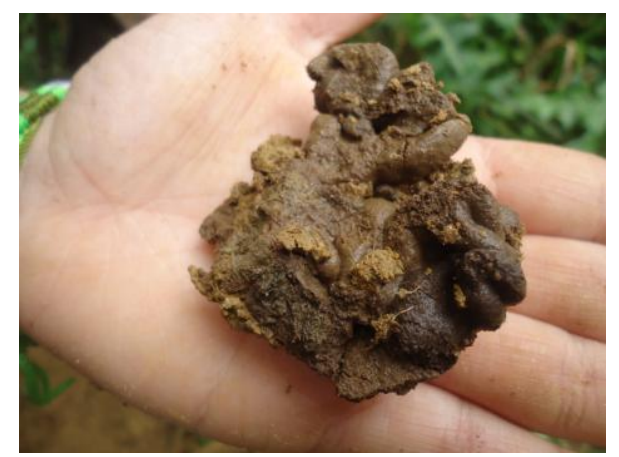

B - Irregular block of very large size

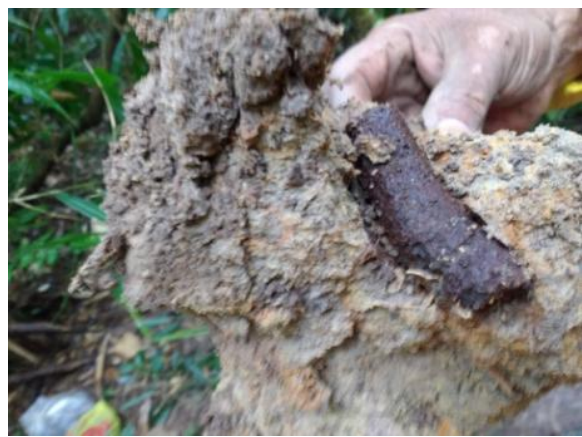

D - Old cast in red color, with oxidized wall, and darker than bulk soil

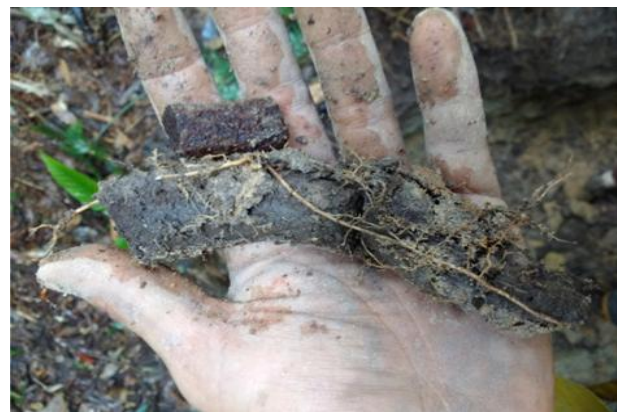

F - Roots next to cylindrical casts

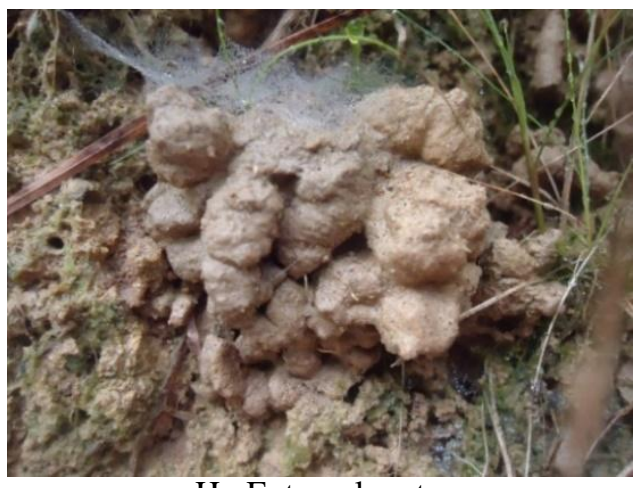

$\mathrm{H}$-External casts

Figure 3: Casts.

The colors of the casts differed between reddish brown (2.5YR 5/3) and black (10YR 2/1), as shown in Figures 3A - 3H. This variation in color can indicate earthworm feeding preferences, as earthworms are generally divided into three overarching ecological categories or functional types: (i) epigeic, or detritivorous earthworms, who live largely at the soil surface and consume only organic matter and leaf litter, resulting in dark colored humic-like excretions; (ii) endogeic, or those that live deep within the mineral soil column and are predominantly geophagous, resulting in casts that have the same color as the soil layer from which they usually feed (Figure 3A); and (iii) anecic species, which are presented as an intermediate category among the others, as they are known to consume both mineral and organic materials (SIMS and GERARD, 1985; FRAGOSO and LAVELLE, 1992; LEE, 1992). 
For the large cylindrical internal casts, surfaces were smooth and had no apparent rings, and they exhibited different colorations on their outer walls. Some had a dark color (Figure 3C) likely indicating them to be recent dejections, while others appeared older and therefore may have already undergone biogeochemical processes in the soil. Evidence for biogeochemical alteration included a visible reddish film that covered many older casts, suggesting oxidation of Fe (Figure 3D). When the worm excrements present a color contrast relative to the surrounding soil matrix, they are easily discernible within the profile. However, if there is no contrast, they can still be identified based on their morphology; earthworm casts generally have smooth and rounded shapes (Figure 3E) distinct from abiotic physical aggregates (square/angular). Plant roots also commonly follow the preferential flow paths where casts accumulate (Figure 3F), likely due to the opening and aeration of the soil promoted by earthworm burrowing. The casts composition may also invite root systems because these earthworm casts are nutrient-rich, as confirmed through chemical analysis (item 3.2).

While feeding on the soil, earthworms destroy its initial structure and re-create a new pedosphere. Their dejections are composed of organo-mineral colloids (the plasma), mineral grains, and plant residues more resistant to digestion (skeleton). At the onset of earthworm digestion, the ingested litter is crushed by the muscle contractions of the gizzard with the aid of ingested sand, which aids in fragmentation. Alongside these actions promoting physical disintegration of the soil material, microbes and enzymes in the intestine drive chemical dissolution, and they (along with clays) act as binding agents during the digestive process. The posterior intestine is drier and begins to "compact" the material. When it is excreted, the 'plasma' coagulates, cementing the organo-mineral 'skeleton' (ROBERT and BERTHELIN, 1986; SHIPITALO and PROTZ, 1989; BAROIS et al., 1993). Fresh casts (Figure 3G) are often still very humid. When they are deposited in a dry environment, they can stabilize and be preserved for a long time, thereby becoming important structural soil components. Local water conditions (i.e. rainfall, atmospheric, and soil moistures) may also influence the stabilization of these bio-structures, given their environmental sensitivity (Figure 3H).

In addition to climatic factors, cast structural coherence also depends on the "glue" effect of bacteria inside them, along with the hyphae and fungi that grow around and on them (LYNCH and BRAGG, 1985; Lee, 1992). For Bachelier, "the resistance of the aggregates is linked to the stabilization of these products by microbial synthesis and notably to the growth of links between polysaccharides and mineral surfaces" (1978, p. 51). The root system, especially when very dense, can help maintain the cohesion of the casts. The formation of cutans on the walls of these structures has been recorded previously, and may further contribute to their stabilization (ALLISON FRANKLIN, 1968 apud BACHELIER, 1978).

In the tropics, the production of casts typically varies from between 50-2,600 ton $^{-1} \mathrm{ha}^{-1}$ year ${ }^{-1}$, corresponding to the movement of $\sim 10 \mathrm{~cm}$ of soil over a period of six months to 30 years. Earthworms absorb less than $10 \%$ of the material they consume. Their feces, which is rich in nutrients, can subsequently be digested again by other earthworms or coprophagous animals (BAL, 1982; LEE, 1985). Repeated cycles of ingestion and excretion (biological weathering), along with background physical and chemical weathering of soils, collectively act to fragment and alter the bioaggregates, which become smaller with time (LEE, 1992).

\subsubsection{Pedotubes}

We found large variations in the size (i.e. average diameter) of pedotubes along our catena. We also noted that some crotovines were notably infilled by casts (Figure 4A), while others were not (Figure 4B). Crotovines are old channels that have been subsequently filled with materials from other soil layers due to ongoing physical and/or biological processes (CURI, 1993). According to Bachelier (1978), earthworms only excrete their casts in abandoned galleries. In some of the bio- structures that were smaller in size, the cylindrical outline was noticeable. In these instances, the pedotube also had a dark color that differed from the bulk soil, indicating incorporation of organic matter into the mineral layer (Figure 4A). 


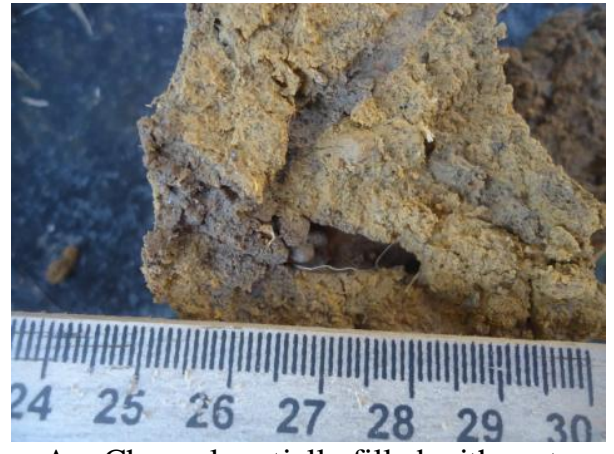

A - Channel partially filled with casts darker in color than bulk soil
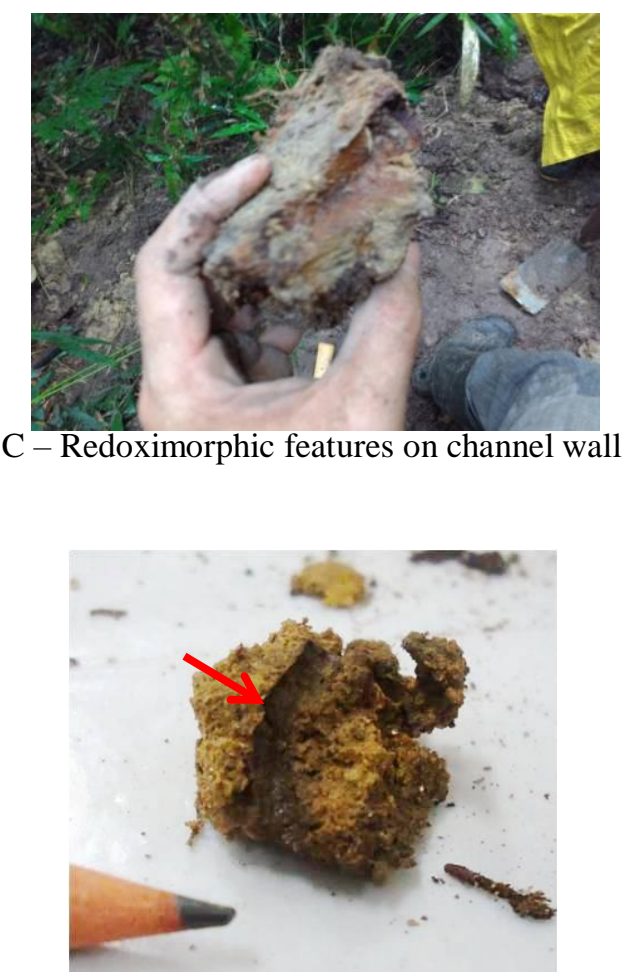

E - Mucous discharge at worm channel wall

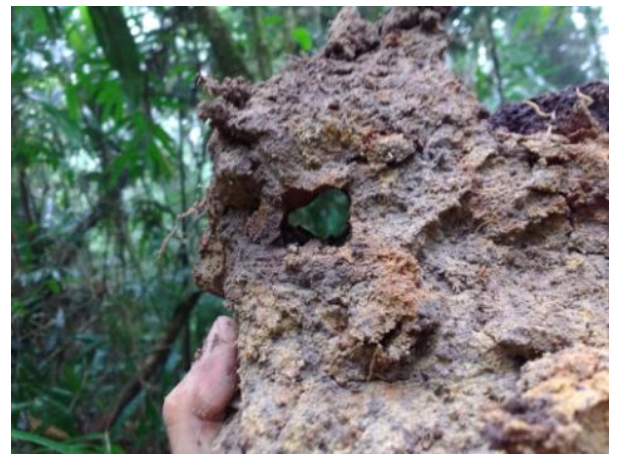

B - Large pedotube

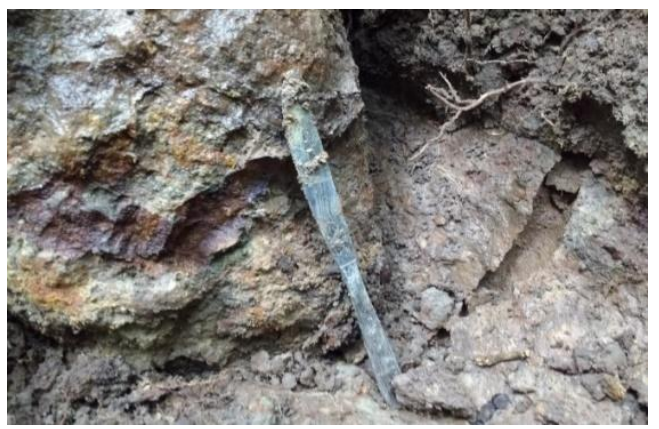

$\mathrm{D}$ - Redoximorphic features in a rock fragment close to a worm channel

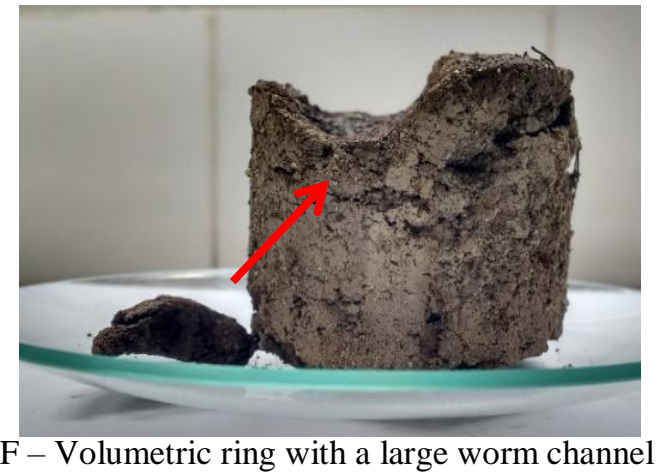

Figure 4: Pedotubes (channels)

Redoximorphic features were also very common on channel walls. The space between the excretion and the gallery wall allows for the gas exchange between the soil and the atmosphere, causing the materials to oxidize in the area immediately surrounding the dejection (Figure 4C). This phenomenon was not only observed throughout the soil column, but also in the rock fragment walls bordered by casts (Figure 4D). Mottles were fairly abundant, medium to large in size, and yellow-red (5YR 4/6) to light reddish-brown (2.5YR 7/4) in color, as indicated in Figures 3D, 4C, and 4D. Kretzschmar and Monestiez (1992) consider that these biogenic ducts contribute to $\mathrm{O}_{2}$ renewal and $\mathrm{CO}_{2}$ removal from the soil; therefore, bioturbation may also exert a force contrary to the creation of anaerobic micro- and macro-structures in soil aggregates.

A significant portion of soil macropores are excavated by soil macrofauna, especially earthworms (LEE, 1992). Water circulation in bulk soil is often lower relative to circulation in annelid channels (SMETTEM, 1992). Hydrologic circulation through biogenic cavities is different from circulation in other pores because earthworm channels are rich in nutrients, organic matter, and microorganisms, and also represent preferential sites for root growth and development. The chemically rich solutions that percolate downwards through the soil profile along these preferential flow paths help maintain soil fertility in deeper layers (BACHELIER, 1978). We also observed mucus secreted through the epidermis of earthworms along several channel walls (Figure 4E). Previously, it has been shown that earthworm mucus can display hydrophobic behavior that helps to stabilize biogenic wall channels, allowing them to remain stable and consolidated even under high levels of soil moisture (KRETZCHMAR, 1998; LEUE et al., 2015). Biogenic channels were also found in the middle of some volumetric rings (Figure 4F). 
Macroaggregates produced by earthworms in Côte d'Ivoire were found to modify the density of the soil, improve its porosity, and favor rapid water infiltration (BLANCHART et al., 1997). In France, earthworm galleries with lengths greater than 40 meters per $\mathrm{m}^{3}$ have already been registered (LOPES ASSAD, 1987 apud MELO JÚNIOR, 2012). This biogenic drainage network can modify vertical or lateral circulation patterns and significantly influences the flow of nutrients and waters through soils, both superficially and deeper down in subsoil environments. Their specific effects may also differ by species or functional type. While endogeic species contribute to lateral water circulation through the construction of horizontal channels, anecic species preferentially facilitate vertical infiltration.

\subsection{Physical and chemical attributes}

Earthworm casts and the bulk soil maintain similar textures: both are Sandy Loams (Figure 5). This finding suggests that there is no selectivity in relation to the mineral particles size ingested by the worms, at least within this study area. A greater proportion of fine fraction materials have been reported in casts relative to undisturbed soil; however, the intensity of this granulometric selection likely depends both on the pre-existing soil texture as well as on the ecological behavior of earthworms (BLANCHART et al., 2004, RUIZ et al., 2006; JOUQUET et al., 2008). However, only large earthworm casts and their sand, silt, and clay fractions were analyzed here. In future work, we recommend additional detailed investigation of smaller earthworm casts and the other granulometric fractions (i.e. very coarse, coarse, medium, fine, and very fine sand). It has also been previously shown that a selection of particular grain sizes can occur during the transport and/or ingestion of soil or sediment particles by biota. When this material is displaced and (often) deposited on the surface, it may form a "biomantle" with a particle size class distinct from that of the soil matrix that has not undergone bioturbation (JOHNSON, 1990; JOHNSON et al., 2005).

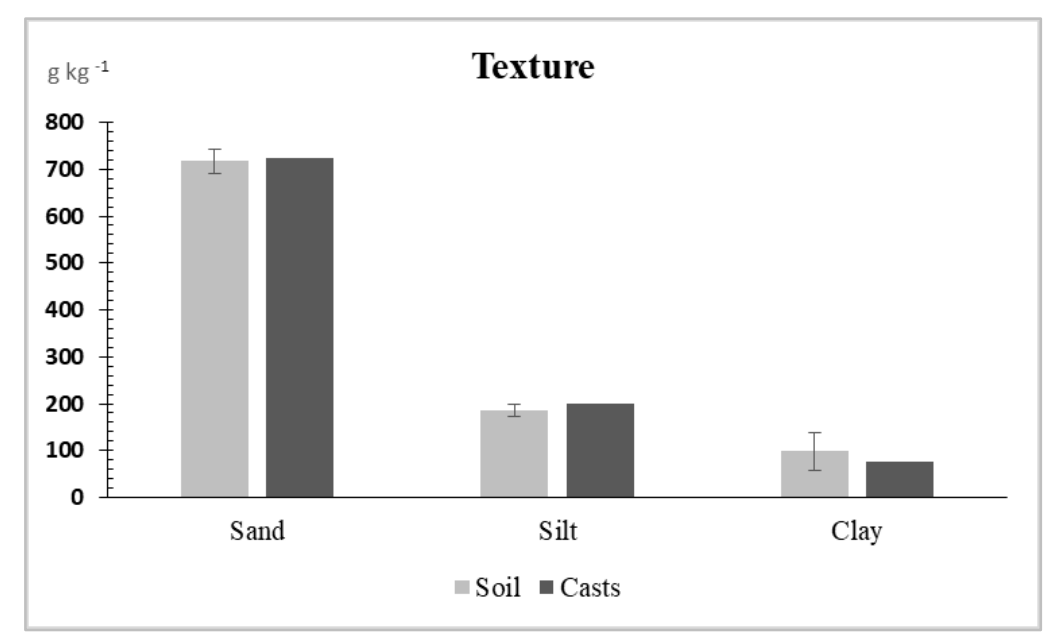

Figure 5: Texture of bulk soil and casts

Bioturbation not only effects solid mineral particles but also microfloral and microfaunal dispersion. As most of these life forms cannot move autonomously, they depend on other organisms for transportation, wherein they may be ingested in one place and subsequently deposited in another (BACHELIER, 1978; MEYSMAN, 2006). Fresh casts may also contain between $10^{3}$ to $10^{4}$ more microorganisms than bulk soils (RIGHI, 1999). By promoting litter fragmentation and thereby increasing the specific surface area of available soil organic matter, earthworms promote conditions that favor microbial proliferation. Nitrifying bacteria are often concentrated in their excrement (SIMS and GERARD, 1985; RIGHI, 1999; SCHAETZL and ADERSON, 2005). In addition, the physical turnover driven by earthworms excreting casts on the surface and burying fresh plant litter may ultimately make it more easily decomposed by soil biota (LEE, 1992).

Some coprolites had a darker color than the soil layers within which they were found - even when compared to the A-horizon - suggesting an organic matter increase in soils that arises from bioturbation processes. This hypothesis was corroborated by our elemental analyses. We found that earthworm casts contain higher quantities of organic carbon than the bulk soil (Figure 6). The casts also contained higher concentrations of $\mathrm{P}, \mathrm{K}^{+}, \mathrm{Ca}^{2+}$ and $\mathrm{Mg}^{2+}$ (Figure 7). 


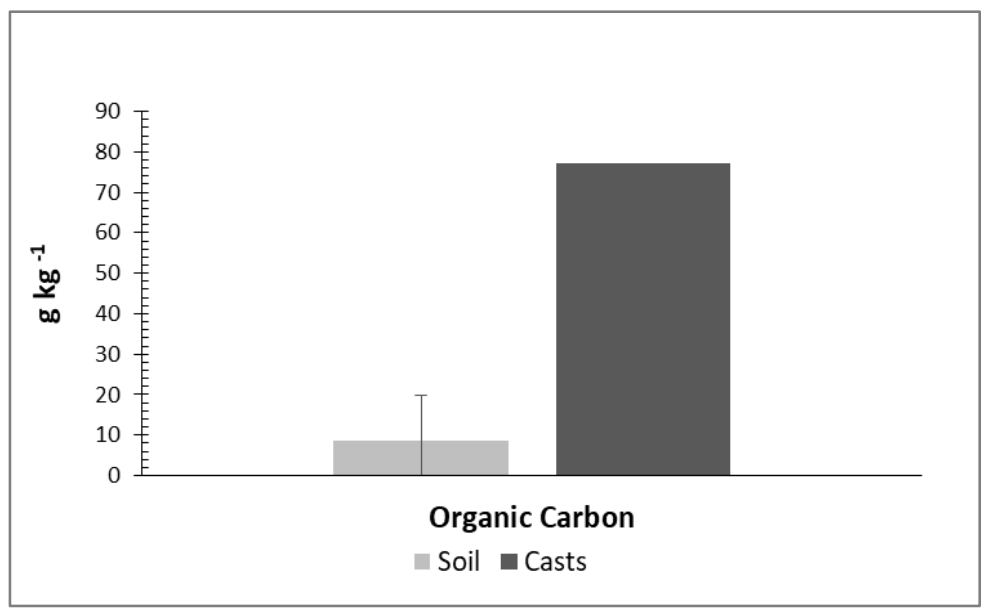

Figure 6: Carbon of bulk soil and casts.

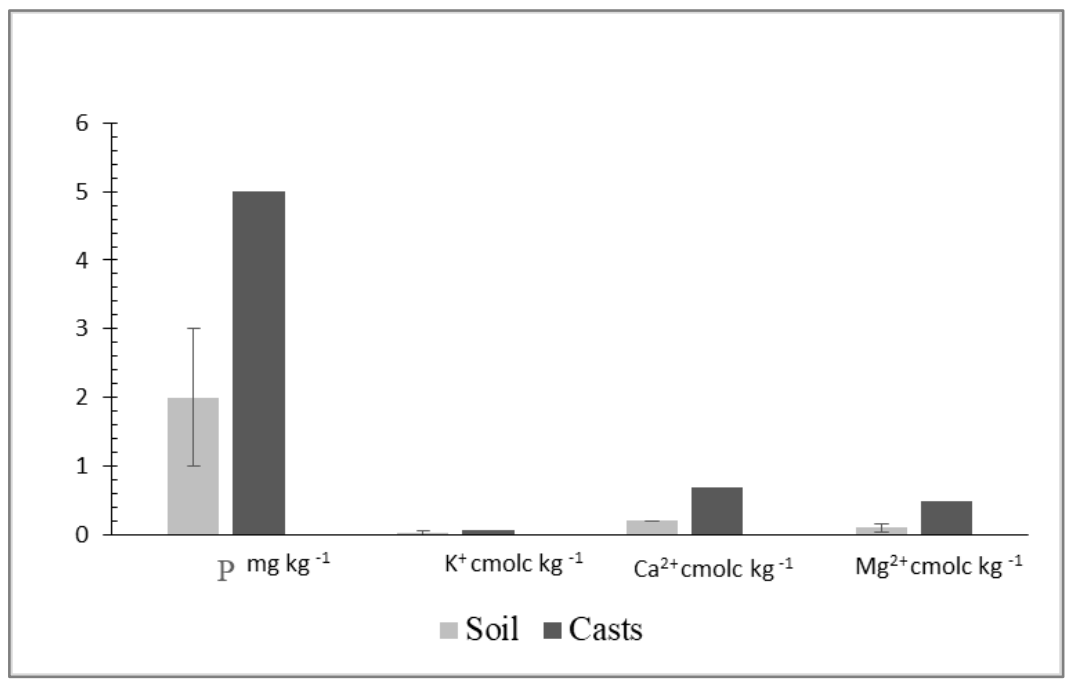

Figure 7: Exchangeable bases of bulk soil and casts.

These organic components are partially preserved within the bioaggregates, since the slower circulation of water and air inside the casts can inhibit biochemical reactions (SYERS and SPRINGETT 1983; BARTHOD et al., 2020). Additionally, once they are assimilated into the colloidal complex and become associated with mineral particles, humic acids may also be stabilized inside the casts (BACHELIER, 1978). Earthworms and their feeding/burrowing activities supply roughly $\sim 1-100 \mathrm{~kg} \mathrm{ha}^{-1} \mathrm{year}^{-1}$ of nitrogen to the soil, depending on the size of their populations, their dejections, and the composition of their tissues/mucus while living and following their death. Through the successive passage of plant remains in their intestinal tract, earthworms may also help to lower the $\mathrm{C} / \mathrm{N}$ ratio. They can also excrete calcium carbonate accumulated in their calciferous glands; the neutralization of acidic soils through this natural 'liming' process having been reported previously. Finally, their coprolites are generally richer in exchangeable magnesium and calcium than the surrounding soil, with greater phosphorus availability and elevated CEC (WIECEK and MESSENGER, 1972 apud BACHELIER, 1978; SIMS and GERARD, 1985; LEE, 1992; CURRY, 1998; RIGHI, 1999).

\section{Conclusions}

Here, we evaluated biogenic structures arising from earthworm activity - such as channels and excretions (casts) - from a morphological and analytical perspective. Our site selection allowed us the opportunity to assess biogenic features from only one taxonomic group (earthworms), while ignoring potential contributions from all of the other bioturbating agents that are typically active across the tropics, like termites and ants. Even so, a significant number of biogenic features were present in soils across the study area, and these should be considered during field and laboratory characterization of these soils. Biostructures are easily discernible due to their morphological characteristics within the soil profile. The texture of the bioaggregates did not differ in relation to the bulk soil. However, chemical analyses revealed major differences between the 
chemical composition of earthworm casts relative to the bulk soil, with some casts exhibiting exchangeable base and carbon contents three times greater than the surrounding soil matrix. This data highlights the efficiency of certain annelid ecological groups in bioturbating and physically mixing soils, which delivers organic matter into subsoil environments. Earthworms perform fundamental functions in the soil like aeration, aggregation, and the incorporation of organic matter, all of which may increase fertility and strongly influence pedogenesis. However, soil morphology, genesis, and classification still generally disregard the importance of biogenesis, and do not provide the necessary elements to properly identify and explain biotic and abiotic soil interactions.

\section{Acknowledgments}

"This work was carried out with the support of the Coordination for the Improvement of Higher Education Personnel - Brazil (CAPES) - Financing Code 001".

\section{References}

ALMEIDA, F.F.M. Fundamentos geológicos do relevo paulista. São Paulo: USP, Série Teses e Monografias - 14; 1974.

BACHELIER, G. La faune des sols. Son écologie et son action. Paris: Orstom. Init. Doc. Tech. n. 38; 1978. Bal, L. Zoological Ripening of Soils. Wageningen: Centre for Agricultural Publishing and Documentation; 1982.

BAROIS, I.; VILLEMIN, G.; LAVELLE, P.; TOUTAIN, F. Transformation of the soil structure through Pontoscolex corethrurus (Oligochaeta) intestinal tract. Geoderma. v. 56, 57-66, 1993. DOI: 10.1016/B9780-444-81490-6.50010-8

BARTHOD, J.; DIGNAC, M. F.; LE MER, G.; BOTTINELLI, N.; WATTEAU, F.; KÖGEL-KNABNER, I.; RUMPEL, C. How do earthworms affect organic matter decomposition in the presence of clay-sized minerals? Soil Biology and Biochemistry. v. 143, p. 107730, 2020. DOI: 10.1016/j.soilbio.2020.107730

BLANCHART, E.; LAVELLE, P.; BRAUDEAUS, E.; LE BISONAIS, Y.; VALENTIN, C. Regulation of soil structure by geophagous earthworm activities in humid savannas of Côte d'Tvoire. Soil Biology and Biochemistry., v. 29, 431-439, 1997. DOI: 10.1016/S0038-0717(96)00042-9

BLANCHART, E.; ALBRECHT, A.; CHEVALLIER, T.; HARTMANN, C. The respective roles of roots and earthworms in restoring physical properties of Vertisol under a Digitaria decumbens pasture (Martinique, WI). Agriculture, ecosystems \& environment. v. 103, n. 2, p. 343-355, 2004. DOI: 10.1016/j.agee.2003.12.012.

CAMPANHA, G. A.; ENS, H. H.; PONÇANO, E.; WALDIR L. Análise morfotectônica do Planalto do Juqueriquerê, São Sebastião (SP). Brazilian Journal of Geology. v. 24, 32-42, 1994.

CURI, N. Vocabulário de ciência do solo. Campinas: Sociedade Brasileira de Ciência do Solo; 1993.

CURRY, J. P. Factors affecting earthworm abundance in soils. In: EDWARDS, C. A. (Orgs.). Earthworm ecology. Boca Raton: CRC Press LCC, 1998, p. 37-64.

CUSTÓDIO FILHO, A. Flora da Estação Biológica de Boracéia: Listagem de espécies. Revista do Instituto Florestal. v.1. 161-199, 1989.

DONAGEMMA, G.K., CAMPOS, D.V.B., CALDERANO, S.B., TEIXEIRA, W.G., VIANA, J.H.M. Manual de métodos de análise do solo. 2nd ed. Rio de Janeiro: Centro Nacional de Pesquisa do Solo Embrapa Solos; 2011.

EMPRESA BRASILEIRA DE PESQUISA AGROPECUARIA. Manual de métodos de análise de solo. 2. ed. Rio de Janeiro: EMBRAPA-CNPS; 1997. 
EMPRESA BRASILEIRA DE PESQUISA AGROPECUARIA. Sistema brasileiro de classificação de solos. 3. ed. Brasília: EMBRAPA; 2018.

FAO (Food and Agricultural Organization of the United Nations). Guidelines for soil description. Rome: Food and Agricultural Organization of the United Nations; 2006.

FRAGOSO, C.; LAVELLE, P. Earthworm communities of tropical rain forests. Soil Biology and Biochemistry. v. 24, n. 12, 1397-1408, 1992. DOI: 10.1016/0038-0717(92)90124-G

HOLE, F. D. Effects of animal on soil. Geoderma. v. 25, 75-112, 1981. DOI: 10.1016/0016-7061(81)900082

HOLT, J. A.; LEPAGE, M. Termites and soil properties. In: ABE, T.; BIGNELL, D. E.; HIGASHI, M. (Orgs.). Termites: evolution, sociality, symbioses, ecology. Netherlands: Springer Science \& Business Media, 2000, p. 389-407.

INSTITUTO BRASILEIRO DE GEOGRAFIA E ESTATÍSTICA-IBGE. Manual Técnico de Pedologia, 2 ed. Rio de Janeiro, 2007.

INSTITUTO BRASILEIRO DE GEOGRAFIA E ESTATÍSTICA-IBGE. Mapas Interativos, 2005. Disponível em: <http://mapas.ibge.gov.br>.

INSTITUTO BRASILEIRO DE GEOGRAFIA E ESTATÍSTICA-IBGE. Manual Técnico da vegetação brasileira. 2 ed. Rio de Janeiro, 2012.

IUSS WORKING GROUP WRB. World reference base for soil resources 2006. A framework for international classification, correlation and communication. World Soil Resources Reports No. 103. Rome, FAO; 2006.

IUSS WORKING GROUP WRB. World Reference Base for Soil Resources 2014, update 2015 International soil classification system for naming soils and creating legends for soil maps. World Soil Resources Reports No. 106. Rome, FAO; 2015.

JOHNSON, D. L. Biomantle evolution and the redistribution of earth materials and artifacts. Soil Science. v. 149, 84-102, 1990. DOI: 10.1097/00010694-199002000-00004

JOHNSON, D.; WATSON-STEGNER, D.; JOHNSON, D. N.; SCHAETZL, R. J. Proisotropic and proanisotropic processes of pedoturbation. Soil Science. v. 143, 278-292, 1987. DOI: 10.1097/00010694198704000-00005

JOHNSON, D. L.; DOMIER, J. E. J.; JOHNSON, D. N. Reflections on the nature of soil and its biomantle. In: Annals of the Association of American Geographers, v. 95, 11-31, 2005. DOI: 10.1111/j.1467-8306.2005.00448.x

JONES, C. G; LAWTON, J. H; SHACHAK, M. Organisms as ecosystem engineers. Ecosystem Management. v. 14, 130-147, 1994. DOI: 10.1007/978-1-4612-4018-1_14

JOUQUET, P.; HARTMANN, C.; CHOOSAI, C.; HANBOONSONG, Y.; BRUNET, D.; MONTOROI, J. P. Different effects of earthworms and ants on soil properties of paddy fields in North-East Thailand. Paddy and Water Environment. v. 6, n. 4, p. 381-386, 2008. DOI: 10.1007/s10333-008-0134-x

KRETZSCHMAR, A. Earthworm interactions with soil organization. In: EDWARDS, C. A. (Orgs.). Earthworm ecology. Boca Raton: CRC Press LCC, 1998. p. 163-176.

KRETZSCHMAR, A.; MONESTIEZ, P. Physical control of soil biological activity due to endogeic earthworm behaviour. Soil Biology and Biochemistry. v. 24, 1609-1614, 1992. DOI: 10.1016/00380717(92)90158-T 
LAVELLE, P.; BIGNELL, D.; DHILLION, S.; HEAL, O.W.; INESON, P.; LEPAGE, M.; ROGER, P.; WOLTERS, V. Soil function in a changing world: the role of invertebrate ecosystem engineers. European Journal of Soil Biology. v. 33, 159-193, 1997.

LEE, K. E. Some trends and opportunities in earthworm research or: Darwin's children - the future of our discipline. Soil Biology and Biochemistry. v. 24, 1765-1771, 1992. DOI: 10.1016/0038-0717(92)90185-Z

LEE, K. E. Earthworms: their ecology and relationships with soils and land use. London: Academic Press Inc.; 1985.

LEMOS, R. C; SANTOS, R. D. Manual de descrição e coleta de solo no campo. 3. ed. Campinas: Sociedade Brasileira de Ciência do Solo; 1996.

LEUE, M.; GERKE, H. H.; GODOW, S. C. Droplet infiltration and organic matter composition of intact crack and biopore surfaces from clay-illuvial horizons. Journal of Plant Nutrition and Soil Science. v. 178, n. 2, p. 250-260, 2015. DOI: 10.1002/jpln.201400209

LYNCH, J. M.; BRAGG, E. Microorganisms and soil aggregate stability. In: STEWART, B.A. (Orgs). Advances in soil science. Springer New York, 1985, p. 133-171.

MANFREDINI, S.; FURIAN, S. D. M.; QUEIROZ NETO, J. P.; OLIVEIRA, D.; FERREIRA, R. Técnicas em Pedologia, In: VENTURI, L. A. B. (Orgs). Praticando Geografia, 1, 2005, p. 85-98.

MELO JÚNIOR, H. B. Estruturas biogênicas em latossolos de chapadões, Uberlândia - MG. Dissertação (Mestrado em Agronomia). Universidade Federal de Uberlândia, Minas Gerais, 2012.

MEYSMAN, F. J. R.; MIDDELBURG, J. J.; HEIP, C. H. Bioturbation: a fresh look at Darwin's last idea. Trends in Ecology \& Evolution. v. 21, 688-695, 2006. DOI: 10.1016/j.tree.2006.08.002

MIKLOS, A. A. W. Biodynamique d'une couverture pédologique dans la région de Botucatu. Brésil. Thèse de doctorat. Université Paris VI. Académie de Sciences de Paris, 1992, p.438.

MIKLÓS, A. A. W. Biogênese do solo. Revista do Departamento de Geografia-USP. Volume Especial 30 Anos, 190-229, 2012. DOI: 10.7154/RDG.2012.0112.0011

MIKLÓS, A. A. W. Conceito Ecológico do Solo: O Papel da Biodiversidade na Organização e Dinâmica da Cobertura Pedológica. Agricultura Biodinâmica. v. 14, 11-16, 1997.

MYERS, N.; MITTERMEIER, R.A.; MITTERMEIER, C.G.; DA FONSECA, G.A.; KENT, J. Biodiversity hotspots for conservation priorities. Nature. v. 403, 853-858, 2000. DOI: 10.1038/35002501

ODUM, E.P. Ecologia. Rio de Janeiro: Guanabara Koogan S. A.; 1983.

OLIVEIRA, J. D.; CAMARGO, M. D.; ROSSI, M.; CALDERANO, F, B. Mapa pedológico do Estado de São Paulo: legenda expandida. Campinas: Instituto Agronômico; 1999.

RIBEIRO, M.C.; J.P. METZGER; A.C. MARTENSEN; F.J. PONZONI.; M.M. HIROTA. The Brazilian Atlantic Forest: How much is left, and how is the remaining forest distributed? Implications for conservation. Biological conservation. v. 142, 1141-1153, 2009. DOI: 10.1016/j.biocon.2009.02.021

RIGHI, G. OLIGOCHAETA, A. Diversidade e agroecologia, 1999. Biodiversidade do Estado de São Paulo, Brasil. São Paulo: Fundação de Amparo à Pesquisa do Estado de São Paulo; 1995.

ROBERT, M.; BERTHELIN, J. Role of Biological and Biochemical Factors in Soil Mineral Weathering. Interactions of soil minerals with natural organics and microbes. 453-495, 1986. DOI: 10.2136/sssaspecpub17.c12

ROSS, J.L.; MOROZ, F.C. Mapa Geomorfológico do Estado de São Paulo. Escala 1:500000, v.1, São Paulo: FFLCH-USP, IPT, FAPESP; 1997. 
ROSSI, M.; QUEIROZ NETO, J. P. Relações solo/paisagem em regiões tropicais úmidas: o exemplo da Serra do Mar em São Paulo, Brasil. Revista do Departamento de Geografia. v. 14, 11-23, 2001. DOI: 10.7154/RDG.2001.0014.0001

RUIZ, M. P.; RAMAJO, M.; JESÚS, J. B.; TRIGO, D.; COSÍN, D. D. Selective feeding of the earthworm Hormogaster elisae (Oligochaeta, Hormogastridae) in laboratory culture. European journal of soil biology. v. 42, p. S289-S295, 2006. DOI:

SCHAEFER, C. E. R. Brazilian latosols and their B horizon microstructure as long-term biotic constructs. Soil Research. v. 39, n. 5, p. 909-926, 2001. DOI: 10.1071/SR00093

SCHAETZL, R. J; ANDERSON, S. Soil genesis and geomorphology. New York: Cambridge University Press; 2005.

SHIPITALO, M. J.; PROTZ, R. Chemistry and micromorphology of aggregation in earthworm casts. Geoderma. v. 45, 357-374, 1989. DOI: 10.1016/0016-7061(89)90016-5

SIMS, R. W.; GERARD, B. M. Earthworms: Keys and Notes for the Identification and Study of the Species. London: Brill/Backhuys; 1985.

SMETTEM, K. R. J. The relation of earthworms to soil hydraulic properties. Soil Biology and Biochemistry. v. 24, 1539-1543, 1992. DOI: 10.1016/0038-0717(92)90147-P

SYERS, J. K.; SPRINGETT, J. A. Earthworm ecology in grassland soils. In: EDWARDS, C. A. (Orgs.). Earthworm ecology. Boca Raton: CRC Press LCC, 1998, p. 67-83.

(1) (우 (2)

Este artigo é distribuído nos termos e condições do Creative Commons Attributions/AtribuiçãoNãoComercial-CompartilhaIgual (CC BY-NC-SA). 